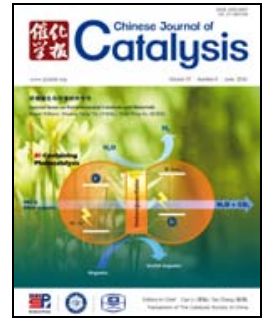

Review (Special Issue on Environmental Catalysis and Materials)

\title{
Adsorptive and catalytic properties in the removal of volatile organic compounds over zeolite-based materials
}

\author{
Ling Zhang a, Yuexin Peng a, Juan Zhanga a, Long Chen b, Xiangju Meng a,*, Feng-Shou Xiao a,\# \\ a Key Laboratory of Applied Chemistry of Zhejiang Province, Department of Chemistry, Zhejiang University, Hangzhou 310007, Zhejiang, China \\ ${ }^{\mathrm{b}}$ Faculty of Chemistry Biology and Materials Science, East China Institute of Technology, Fuzhou 344000, Jiangxi, China
}

A R T I C L E I N F O

Article history:

Received 30 January 2016

Accepted 3 March 2016

Published 5 June 2016

\section{Keywords:}

Air pollution

Volatile organic compound

Zeolite

Supported catalyst

Catalytic combustion

\begin{abstract}
A B S T R A C T
Volatile organic compounds (VOCs) are a major component in air pollutants and pose great risks to both human health and environmental protection. Currently, VOC abatement in industrial applications is through the use of activated carbons as adsorbents and oxide-supported metals as catalysts. Notably, activated carbons easily adsorb water, which strongly hinders the adsorption of VOCs; conventional oxides typically possess relatively low surface areas and random pores, which effectively influence the catalytic conversion of VOCs. Zeolites, in contrast with activated carbons and oxides, can be designed to have very uniform and controllable micropores, in addition to tailored wettability properties, which can favor the selective adsorption of VOCs. In particular, zeolites with selective adsorptive properties when combined with catalytically active metals result in zeolite-supported metals exhibiting significantly improved performance in the catalytic combustion of VOCs compared with conventional oxide-supported catalysts. In this review, recent developments on VOC abatement by adsorptive and catalytic techniques over zeolite-based materials have been briefly summarized.
\end{abstract}

(C) 2016, Dalian Institute of Chemical Physics, Chinese Academy of Sciences. Published by Elsevier B.V. All rights reserved.

\section{Introduction}

Volatile organic compounds (VOCs) usually refer to organic compounds having boiling points within the range of $50-260^{\circ} \mathrm{C}$ [1-5], principally attributed to combustion engine and industrial emissions as well as domestic products. VOCs generally have high-risk biological toxicity properties, which pose significant threat to the human health. Additionally, VOCs are precursors to ozone and photochemical smog, which is a global issue for environmental protection. Therefore, VOC abatement has received ever increasing attention. Hitherto, there are numerous reported processes dealing with established VOC abatement, such as adsorption [6], thermal incineration [7], photocatalytic [8], plasma catalytic oxidation [9], and catalytic combustion [10]. Among these techniques, VOC abatement by adsorption is widely employed at present because of simple operational procedures and economic viability in industrial applications, while catalytic combustion has been considered as one of the most effective methods because of its economically feasibility and high efficiency. Furthermore, the catalytic combustion process generates $\mathrm{CO}_{2}$ as the only combustion product. Thus, there is a current need to develop highly efficient tailored adsorbents and catalysts.

Zeolites are regarded as one of the most industrially rele-

\footnotetext{
* Corresponding author. Tel/Fax: +86-571-88273698; E-mail: mengxj@zju.edu.cn

\# Corresponding author. Tel/Fax: +86-571-88273698; E-mail: fsxiao@zju.edu.cn

This work was supported by the Fundamental Research Funds for the Central Universities (2015XZZX004-04) and Zhejiang Provincial Natural Science Foundation (LR15B030001). 
vant adsorbents and catalysts because of their large surface areas, high adsorption capacity, high thermal and hydrothermal stability and the ability to tailor properties such as wettability and auxiliary mesopore generation in the crystals. Additionally, the presence of well-defined micropores exhibiting excellent shape-selectivity also contributes to their success. Such physicochemical properties allow zeolites to selectively adsorb VOCs. Furthermore, a series of zeolite-supported metals as highly efficient catalysts have been well developed for the catalytic combustion of VOCs by combination of selective adsorption onto zeolites with catalytically active metal centers. This review presents recent developments regarding the adsorption and catalytic properties in VOC abatement over zeolite-based materials.

\section{Adsorption of VOCs over zeolites}

Adsorption is one common and simple technique for the condensation and recovery of VOCs. Currently, activated carbons are the most useful adsorbents for VOC uptake [11-14], however, employing activated carbons still has practicality issues, such as flammability [15], difficulties in regeneration [16], and humidity control [17]. Compared with activated carbons, zeolites exhibit unique features, such as non-flammability, excellent regeneration by calcination, and controllable surface hydrophobicity hydrophilicity. Therefore, zeolites have shown to be useful alternative adsorbents for selective adsorption of VOCs [18].

Chintawar et al. [19] investigated ambient adsorption of gaseous trichloroethylene (TCE) over chromium exchanged ZSM-5 zeolites with various $\mathrm{SiO}_{2} / \mathrm{Al}_{2} \mathrm{O}_{3}$ ratios under a humid air atmosphere. The study found that when increasing the $\mathrm{SiO}_{2} / \mathrm{Al}_{2} \mathrm{O}_{3}$ ratio from 30 to 120 the TCE saturation capacity of the zeolite increased from 6.0 to $10.1 \mathrm{wt} \%$, attributed to an increase in zeolite surface hydrophobicity. Trichloroethylene adsorption is favored over water molecules as the surface hydrophobicity increases. Bhatia et al. [20] studied the adsorption behaviors of butyl acetate in air over silver-loaded $\mathrm{Y}(\mathrm{Si} / \mathrm{Al}=$ $40)$ and ZSM-5 (Si/Al = 140) zeolites. As shown in Fig. 1, the presence of water vapor in the feed strongly suppresses butyl acetate adsorption of AgY; however, the adsorption capacity of

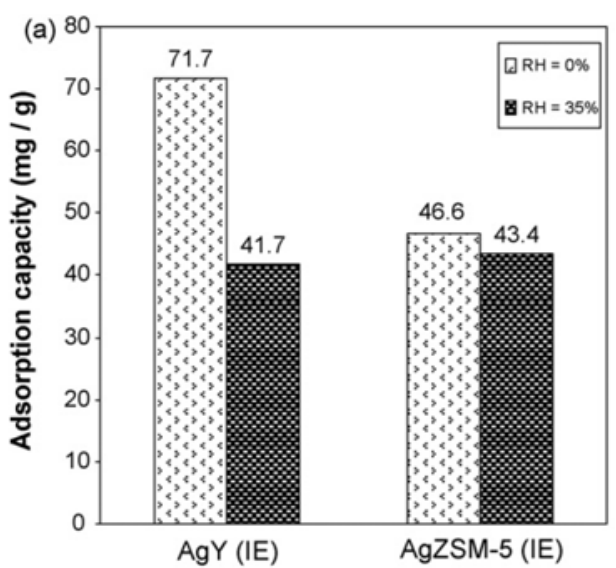

AgZSM-5 is only marginally affected because of the higher hydrophobicity of the zeolite. Huang et al. [21] investigated the changes in hydrophobicity and toluene adsorption-desorption properties of a commercial ZSM-5 zeolite as a function of $\mathrm{Si} / \mathrm{Al}$ ratio and reported that an increase in zeolite $\mathrm{Si} / \mathrm{Al}$ ratio obviously improved the zeolite hydrophobicity, resulting in the favorable adsorption of toluene.

To understand the adsorption of VOCs and water on zeolites, molecular simulation has been employed [22-24]. For example, Güvenç et al. [24] used Monte Carlo simulations to study the relationship between the $\mathrm{Si} / \mathrm{Al}$ ratio of MFI-type zeolites and their adsorptive performance in the removal of hydrophilic methyl tert-butyl ether (MTBE) and hydrophobic trichloroethylene (TCE) mixed with water. Adsorption simulations on the MFI-type zeolites with three different Si/Al ratios $(\infty, 191$, and 95$)$ were performed, showing that increasing zeolite hydrophilicity may significantly reduce MTBE removal from water; while increasing TCE concentration in the TCE-water mixtures leads to water exclusion in high silica zeolites, which may minimize the performance loss of these materials in TCE removal because of the presence of any hydrophilic defects in their structures (Fig. 2) [24].

As size exclusion is a desirable property in zeolite molecular sieves, tuning the zeolite pore size to effectively target the size of the VOCs is also an important factor for the adsorption of VOCs over zeolites. Bulky VOCs, whose size exceeds the zeolite pore dimensions hinders effective adsorption. Nicolas et al. [25] investigated toluene adsorption as a function of zeolite channel size and pore structure using three commercial hydrophobic zeolites: mordenite (MOR), ZSM-5, and faujasite (FAU) zeolite. They evidenced that toluene could be readily absorbed by FAU zeolite, however, decreased adsorption capacities were observed when using MOR and ZSM-5, suggesting the importance of the zeolite structures. Similar results have also been reported by Cosseron et al. [26]. Here they synthesized four pure silica zeolites: chabazite (CHA-structure type), SSZ-23 (STT-structure type), silicalite-1 (MFI-structure type), and beta (*BEA-structure type) for sorption of $n$-hexane, $p$-xylene, and acetone. As the pure silica CHA-type zeolite possesses smaller 8-member rings there was an obvious decrease in the adsorption capacity as a function of increasing molar volume of the

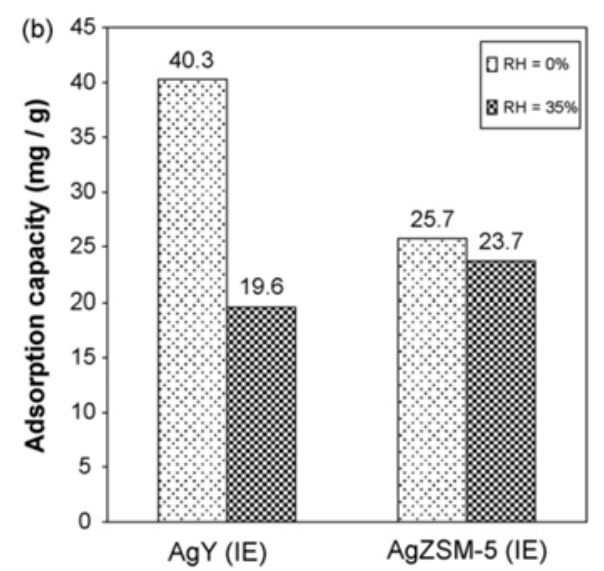

Fig. 1. Butyl acetate uptake by zeolite AgY with $\mathrm{Si} / \mathrm{Al}$ ratio of 40 and AgZSM-5 with Si/Al ratio of 140 . (a) GHSV $=5000 \mathrm{~h}^{-1}, C_{\mathrm{voc}}=4500 \mathrm{ppm}$; (b) GHSV $=5000 \mathrm{~h}^{-1}, C_{\mathrm{voc}}=1000 \mathrm{ppm}$. Reproduced from Ref. [20]. 


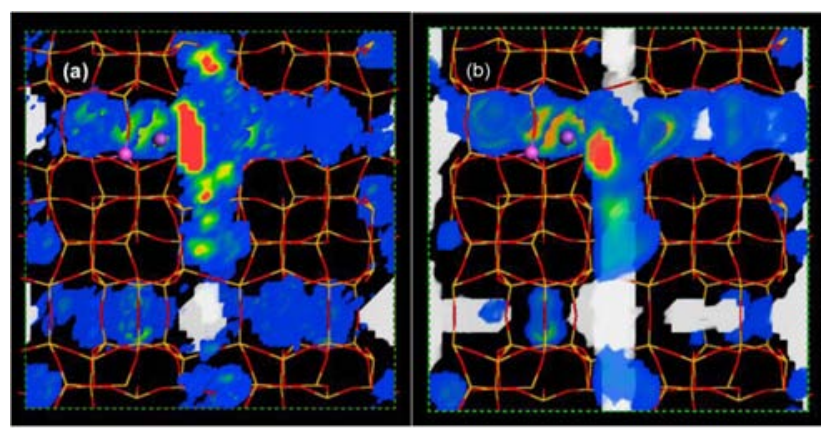

Fig. 2. Methyl tert-butyl ether (a) and trichloroethylene (b) together water density fields in ZSM-5/95 at maximum VOC loading. MTBE/TCE density field is displayed in white, and water density increases from blue (near-zero density) to red. $\mathrm{Al}$ atoms and $\mathrm{Na}^{+}$cations are represented as pink and purple spheres, respectively. Straight and sinusoidal channels run in the vertical and horizontal directions, respectively. Reproduced from Ref. [24].

target probe molecules, preventing VOC ingress to the cages. Brosillon et al. [27] studied co-adsorption of $n$-heptane and acetone over the commercial hydrophobic zeolite, HISIV 3000. They showed that this zeolite displayed good selectivity for acetone even though acetone is more volatile than heptane in the mixture. Corma et al. [28] reported interesting results that there existed two disjunctive pore structures in MCM-22, each of which result in varying VOC adsorption properties with respect to molecular sizes, such as toluene and xylene.

It is not only the wettability of the zeolite that can affect the adsorption performance, as extra-framework cations have also been reported to play a role. For example, Zhou et al. [29] have prepared $\mathrm{Y}$ zeolites with varying metal cations $\left(\mathrm{Li}^{+}, \mathrm{Na}^{+}, \mathrm{K}^{+}, \mathrm{Cs}^{+}\right)$ to study the adsorption performance of aromatic hydrocarbons. They found that the adsorption capacity of the aromatic hydrocarbons on $\mathrm{Y}$ zeolites was dependent on the alkali metal ionic radius, which is attributed to the difference in cationic electronegativity.

The non-flammability properties of zeolites allow for safe regeneration when used as adsorbents. Typically, zeolites adsorbates can be easily regenerated by microwave heating in a relatively short period (rapid heating) with low consumptions of energy [30-32]. Kim et al. [33] reported a study concerning the evaluation of adsorption behaviors as a function of the physicochemical properties of zeolites and investigated the effect of zeolite pore structure on VOC desorption behaviors by microwave heating for regeneration of zeolites from polluted zeolites. They showed that HY901 zeolite had the greatest adsorption capacity because of its larger mesopore volume and microwave heating is effective for desorption of toluene and methylethylketone on the HY901 zeolite.

Remarkable progress in the adsorption of VOCs in recent years has advanced the market and contributed to the commercialization of thermal swing honeycomb rotor adsorbents. Such VOC adsorbent products are characterized by a monolith or honeycomb structure instead of by conventional particles or pellets with a rapid response to temperature swing. This technology was developed by Seibu Giken and Nichias Corporation in Japan, Munters Zeol Corporation in Sweden, and Lurgi Cor- poration in Germany [34-36]. The initial development employed activated carbon as the adsorbent; however, this was replaced soon after by high silica zeolites to avoid possible ignition during hot air thermal regeneration. A slowly rotating honeycomb adsorbent rotor is shown in Fig. 3. During the treatment process, the feed air flows through the narrow channels of the honeycomb structure and the VOC vapors are first removed from the feed air by adsorption onto the adsorbate surface. Thereafter, the adsorbate is regenerated by a hot air stream directed to the process zone. The last section of the rotor is a cooling zone, which is located between the process and regeneration zones, and serves to purge the crude product from the bulk of the fine product and to cool the rotor to maintain high adsorption capacity in the subsequent process zone. In a typical commercial application, $>95 \%$ of VOCs in the feed gas are removed [36], which shows the significance of this technology in the removal of harmful indoor gases.

In summary, the adsorption properties of zeolites can be tailored as a function of framework, microporous structure, $\mathrm{Si} / \mathrm{Al}$ ratio, cations and the hydrophobicity/hydrophilicity nature in zeolites. The outlook of zeolites as efficient and selective adsorbents remains promising.

\section{Catalytic combustion of VOCs over zeolite-supported metal catalysts}

\subsection{Catalytic combustion of aromatics}

Aromatic VOCs, such as benzene and toluene, significantly contribute to industrial and daily life pollutants. Table 1 summarizes recent works on catalytic combustion of aromatics over zeolite-supported metal catalysts. Such catalysts are typically divided by metal type: supported noble metal catalysts and supported transition metal catalysts.

Supported noble metal catalysts have been widely applied in the catalytic combustion of aromatic VOCs, with Pt and Pd being the two commonly used metals practical applications as a result of their catalytic activity.

Chen and co-workers [37-41] have systematically investigated the catalytic performance of toluene combustion over zeolite-supported Pt catalysts. To improve activity, a series of

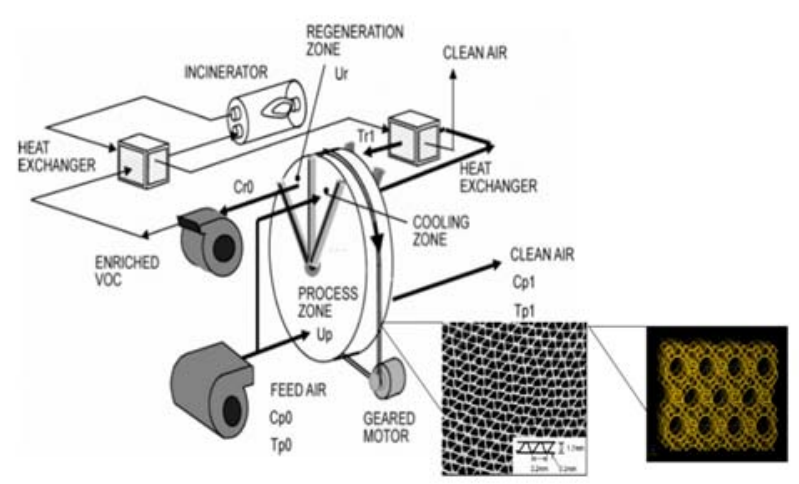

Fig. 3. Integrated VOC abatement system incorporated with a thermal swing honeycomb rotor. Inlet: cross-sectional view of the honeycomb structure. Reproduced from Ref. [36]. 
Table 1

Catalytic activities of zeolite-supported metal catalysts for the combustion of aromatics.

\begin{tabular}{lcccccc}
\hline Catalyst & VOCs & $\begin{array}{c}\text { VOCs } \\
\text { concentration } \\
(\mathrm{ppm})\end{array}$ & $\begin{array}{c}\text { GHSV } \\
\left(\mathrm{h}^{-1}\right)\end{array}$ & $\begin{array}{c}T_{50} \mathrm{~b} \\
\left({ }^{\circ} \mathrm{C}\right)\end{array}$ & $\begin{array}{l}T_{98} \mathrm{~b} \\
\left({ }^{\circ} \mathrm{C}\right)\end{array}$ & Ref. \\
\hline Pt/Meso-Beta & toluene & 1000 & 60000 & 186 & 195 & {$[37]$} \\
Pt/Beta & toluene & 1000 & 60000 & 197 & 212 & {$[37]$} \\
Pt/KZSM-5-60 c & toluene & 1000 & 60000 & 167 & 170 & {$[38]$} \\
Pt/KZSM-5-100 c & toluene & 1000 & 60000 & 162 & 169 & {$[38]$} \\
Pt/Meso-KZSM-5 & toluene & 1000 & 60000 & 172 & 175 & {$[39]$} \\
Pt/KBeta-SDS & toluene & 1000 & 60000 & 142 & 150 & {$[40]$} \\
Pd/Beta-PS d & toluene & 860 & 30000 & 273 & - & {$[46]$} \\
Pd/FAU & toluene & 1000 & 60000 & - & 200 & {$[47]$} \\
NaX & toluene & 800 & 30000 & 357 & 394 & {$[52]$} \\
\hline
\end{tabular}

${ }^{\mathrm{a}}$ Gas hourly space velocity. ${ }^{\mathrm{b}} \mathrm{T}_{50}$ and $T_{98}$ : the temperatures at $50 \%$ and $98 \%$ conversion of VOCs. ${ }^{c} \mathrm{Si} / \mathrm{Al}$ ratio. ${ }^{\mathrm{P}} \mathrm{PS}$ : pure siliceous.

Pt/ZSM-5 zeolites functionalized with different cations $\left(\mathrm{H}^{+}, \mathrm{Na}^{+}\right.$, $\left.\mathrm{K}^{+}, \mathrm{Cs}^{+}\right)$with varying $\mathrm{Si} / \mathrm{Al}$ ratios $(60,100,300, \infty)$ were prepared [38]. As shown in Fig. 4, they observed that the activities of Pt/KZSM-5 and Pt/CsZSM-5 catalysts yielded higher conversions when compared with Pt/HZSM-5 and Pt/NaZSM-5 catalysts, which can be attributed to the difference in the cationic electronegativity. The decrease in cationic electronegativity in the catalysts is favorable for the formation of catalytically active $\mathrm{Pt}^{0}$ species. Catalytic activity as a function of $\mathrm{Si} / \mathrm{Al}$ ratio in the Pt/KZSM-5 catalysts shows a Si/Al ratio of $\sim 100$ to have the highest activity, which is attributed to the hydrophobicity level and $\mathrm{K}^{+}$concentration in the ZSM-5 zeolites. Generally, higher zeolite $\mathrm{Si} / \mathrm{Al}$ ratios improves zeolite hydrophobicity, which is favorable for the adsorption of hydrophobic aromatics. However, further increases to the zeolite $\mathrm{Si} / \mathrm{Al}$ ratio would result in a significant decrease in the $\mathrm{K}^{+}$-exchange ability, which in turn, remarkably reduces $\mathrm{Pt}^{0}$ concentration in the catalysts. Therefore, a balance between the $\mathrm{Si} / \mathrm{Al}$ ratio and $\mathrm{K}^{+}$concentration needs to be considered, and comprehensive studies have shown that the $\mathrm{Si} / \mathrm{Al}$ ratio at $\sim 100$ with suitable hydrophobicity and $\mathrm{K}^{+}$content exhibits the highest activity.

It is not only ZSM-5 zeolites that have been used as supports for the preparation of zeolite-supported metal catalysts. Re-
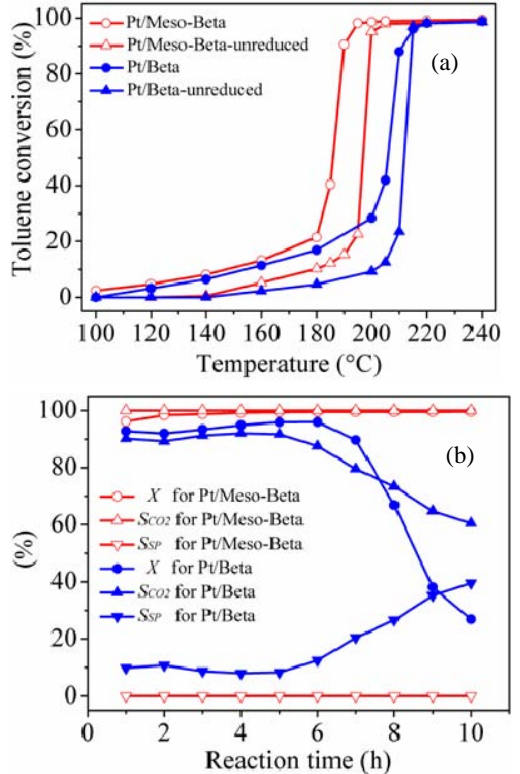

Fig. 5. Catalytic combustion of toluene over Pt/Meso-Beta and Pt/Beta showing (a) catalytic activities and (b) catalyst life. Operating conditions: toluene concentration $1000 \mathrm{ppm}, \mathrm{SV}=60000 \mathrm{~mL} /(\mathrm{g} \cdot \mathrm{h})$. The catalyst life was measured at $193^{\circ} \mathrm{C} . X, S_{\mathrm{C} 02}$, and $S_{\mathrm{SP}}$ correspond to toluene conversion, selectivity for $\mathrm{CO}_{2}$, and selectivity for side products, respectively. Reproduced from Ref. [37].

cently, Chen et al. [40] prepared Pt/KBeta-SDS catalysts using a template-free and seed-directed synthesis (SDS). They showed that the Pt/KBeta-SDS catalyst was highly active, giving a $T_{98}$ value for toluene combustion as low as $150{ }^{\circ} \mathrm{C}$, which is directly attributed to high $\mathrm{K}^{+}$content in the Pt/KBeta-SDS catalyst. To increase mass transfer in the catalytic combustion, mesoporous Beta zeolite was employed as the metal support [37]. As shown in Fig. 5, the mesoporous Beta zeolite-supported Pt catalyst (Pt/Meso-Beta) exhibits significantly improved catalytic activity $\left(T_{98}\right.$ at $\left.195^{\circ} \mathrm{C}\right)$ and longer catalyst life, in addition to a lower apparent activation energy in the catalytic combustion of toluene than the corresponding Pt/Beta catalyst prepared with conventional microporous zeolites $\left(T_{98}\right.$ at $\left.220^{\circ} \mathrm{C}\right)$. Obviously, the presence of mesoporosity in the catalysts is a desired property to enhance both the catalytic activity and lifetime.
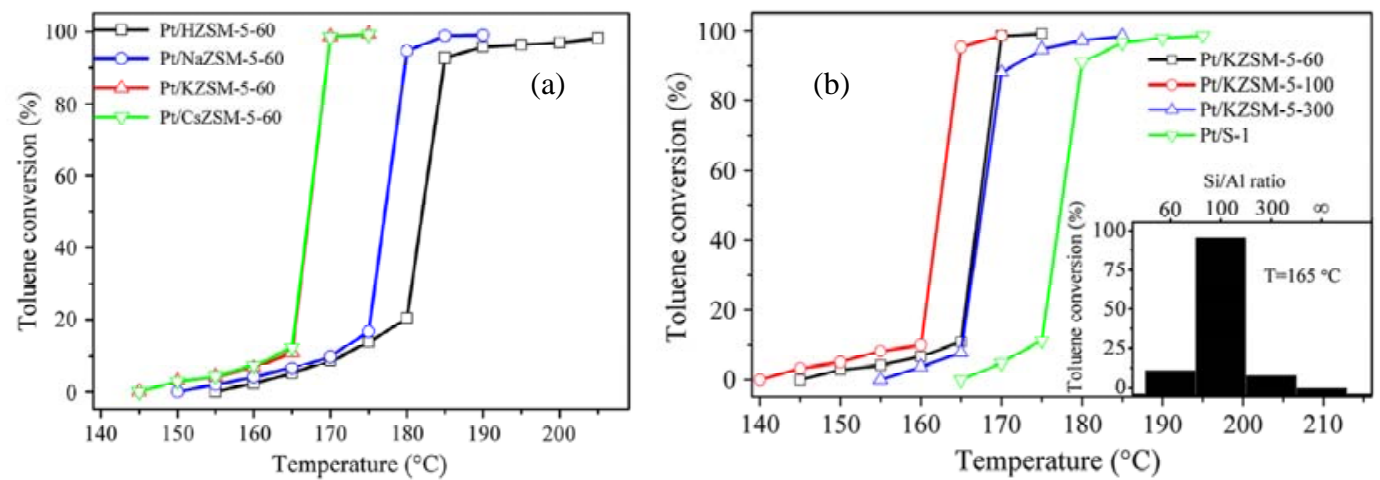

Fig. 4. Catalytic combustion of toluene over (a) zeolite-based catalysts as a function of cation type (Pt/HZSM-5-60, Pt/NaZSM-5-60, Pt/KZSM-5-60, and Pt/CsZSM-5-60) and (b) zeolite-based catalysts with various Si/Al ratios (Pt/KZSM-5-60, Pt/KZSM-5-100, Pt/KZSM-5-300, and Pt/S-1). Operating conditions: toluene concentration $1000 \mathrm{ppm}, \mathrm{SV}=60000 \mathrm{~mL} /(\mathrm{g} \cdot \mathrm{h})$. Inset: Histogram of catalyst activity at $165^{\circ} \mathrm{C}$. Reproduced from Ref. [38]. 

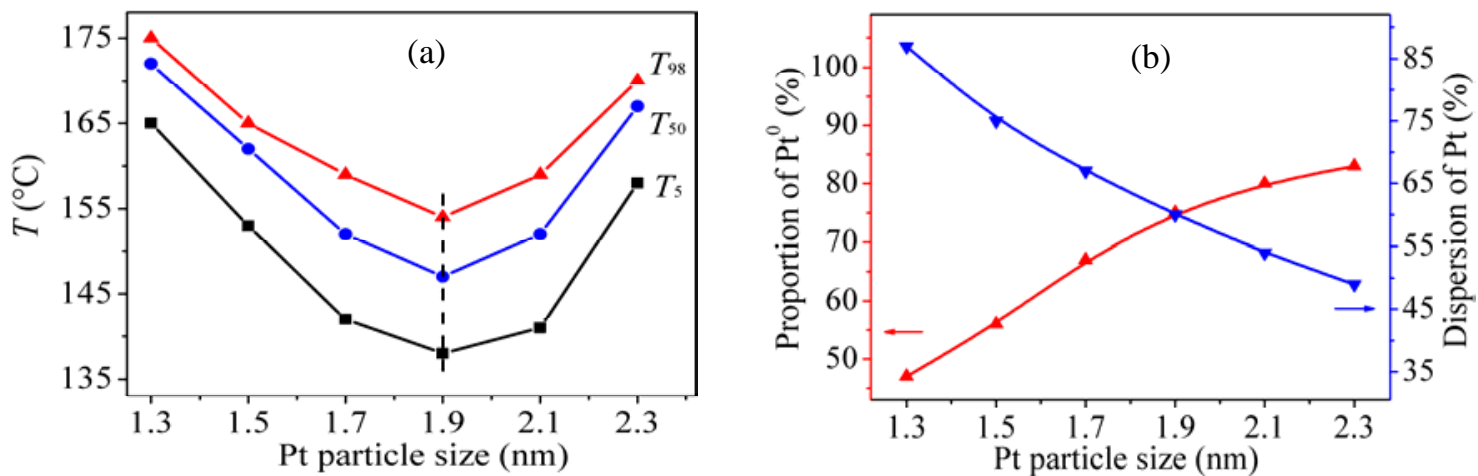

Fig. 6. (a) $T_{5}, T_{50}$, and $T_{98}$ toluene dependence in the complete oxidation of toluene and (b) dependences of Pt dispersion and $\mathrm{Pt}^{0} \mathrm{proportion}$ on $\mathrm{Pt}$ particle size over the Pt- $x$ /ZSM- 5 catalysts. Reproduced from Ref. [41].

Pt particle size plays a key role in how efficient it performs as a catalyst and the effect of Pt particle size on zeolite supports has been widely investigated. For example, Chen et al. [41] have successfully synthesized 1.3-2.3 nm Pt nanoparticles supported on ZSM- 5 zeolites to obtain a series of Pt- $x$ /ZSM- 5 ( $x$ relates to the Pt particle size). As shown in Fig. 6(a), the catalytic activities of the samples are strongly dependent on Pt nanoparticle size. For Pt nanoparticle sizes ranging from 1.3-1.9 nm, the catalytic activities of the samples are enhanced significantly, reaching an apex at $1.9 \mathrm{~nm}$. However, further increasing the $\mathrm{Pt}$ particle sizes to $1.9-2.3 \mathrm{~nm}$ results in a remarked reduction in the sample activities. This activity ordering is obviously related to the trends of both the sample $\mathrm{Pt}^{0}$ proportion and the Pt dispersion (Fig. 6(b)), instead of a comprehensive and independent consideration of both factors. As a result, the Pt-1.9/ZSM-5, combining both a high degree of $\mathrm{Pt}^{0}$ and high levels of Pt dispersion, displays the highest activity among the all catalysts, although possessing a lower degree of $\mathrm{Pt}^{0}$ than that of Pt-2.3/ZSM-5 and a lower Pt dispersion than that of Pt-1.3/ZSM-5. Therefore, optimizing Pt particle sizes plays a significant role for industrial applications of Pt-based catalysts.

Various studies have evidenced that VOC catalytic oxidation in a mixture differs from its simple oxidation and, in general, an inhibiting effect can be observed [42-44]. Beauchet et al. [45] evaluated FAU zeolite performance in the presence or absence of Pt in the oxidation of isopropanol and $o$-xylene alone and mixtures thereof. They described a basic mechanism for propene formation from isopropanol over $\mathrm{NaX}$ (Scheme 1). Thereafter, propene can be directly oxidized or transformed into acetone and/or aldehyde before further oxidation into $\mathrm{CO}_{2}$ and $\mathrm{H}_{2} \mathrm{O}$. While isopropyl dimethylbenzene formed from the alkylation of $o$-xylene by propene, resulting from the dehydration of isopropanol via an acidic mechanism (Scheme 2) over HY zeolite. Afterwards, isopropyl dimethylbenzene can be further oxidized into dimethylphenol and acetone (Scheme 3).

In addition to $\mathrm{Pt}, \mathrm{Pd}$ is an alternative noble metal that can also be supported on zeolite supports for the catalytic combustion of aromatics owing to its relatively low cost [46,47]. Zhang et al. [46] reported the catalytic combustion of toluene over $\mathrm{Pd}$-HBeta catalysts with various $\mathrm{Si} / \mathrm{Al}$ ratios. Remarkable im- provements in catalytic activity was observed as a function of increased $\mathrm{Si} / \mathrm{Al}$ ratio in the Pd-HBeta catalysts. Optimum catalytic activity is found when employing a pure siliceous analogous Beta-related to the strong hydrophobicity of the pure Beta zeolite.

Even though noble metal catalysts display high activities they are not economically viable to be widely applied $[48,49]$. Therefore, the market still requires development of highly ac-

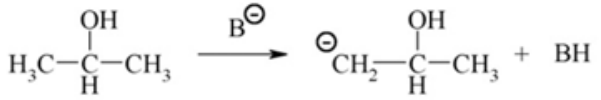

$$
\begin{aligned}
& \overbrace{\mathrm{CH}_{2}}^{\underset{\mathrm{C}}{\mathrm{CH}}-\mathrm{CH}_{3}} \underset{\mathrm{H}}{\mathrm{OH}} \longrightarrow \underset{\mathrm{H}}{\mathrm{C}}-\mathrm{CH}_{3}+\mathrm{OH}^{\ominus} \\
& \mathrm{BH}+\mathrm{OH}^{\ominus} \longrightarrow \mathrm{B}^{\ominus}+\mathrm{H}_{2} \mathrm{O}
\end{aligned}
$$

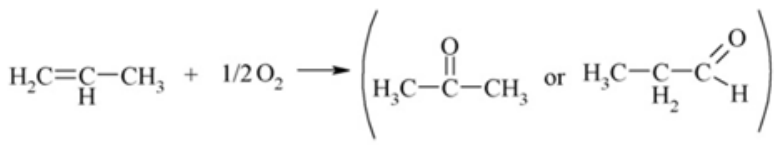

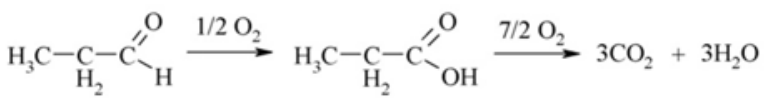

Scheme 1. Basic mechanism for propene formation from isopropanol over NaX. Reproduced from Ref. [45].

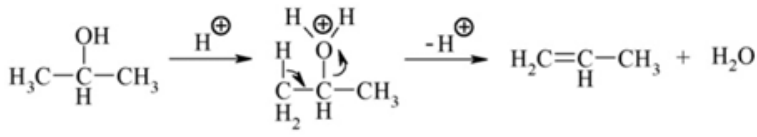

$$
\begin{aligned}
& \mathrm{H}_{2} \mathrm{C}=\underset{\mathrm{H}}{\mathrm{C}}-\mathrm{CH}_{3} \stackrel{\mathrm{H}^{\oplus}}{\longrightarrow} \mathrm{H}_{3} \mathrm{C}-\stackrel{\oplus}{\mathrm{CH}}-\mathrm{CH}_{3}
\end{aligned}
$$

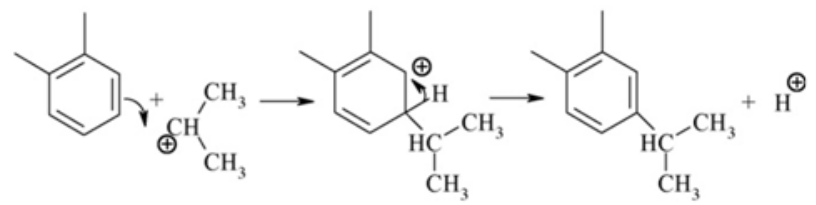

Scheme 2. Dehydration of isopropanol via an acidic mechanism. Reproduced from Ref. [45]. 


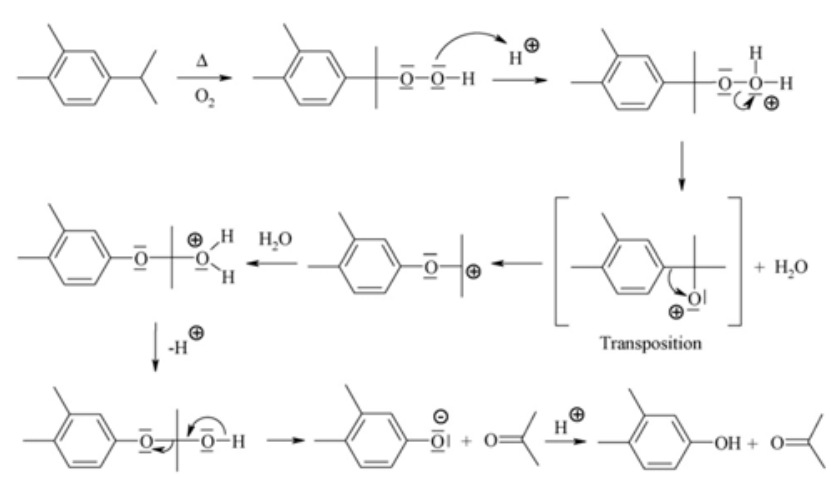

Scheme 3. Isopropyl dimethylbenzene oxidized into dimethylphenol and acetone. Reproduced from Ref. [45].

tive and alternative non-noble metal catalysts. To circumvent this issue, researchers have focused on non-noble metals with empty $d$ orbitals, such as $\mathrm{Ni}, \mathrm{Cu}, \mathrm{Cr}, \mathrm{Co}$, and Mn. Soylu et al. [50] have prepared clinoptilolite zeolite (CLT)-supported $\mathrm{Cu}, \mathrm{Fe}, \mathrm{Co}$ and $\mathrm{Mn}$ transition metals as catalysts for toluene combustion, showing that the zeolite-supported Mn catalyst exhibits relatively high activity, giving $T_{90}$ at $297^{\circ} \mathrm{C}$. Ozcelik et al. [51] systematically studied the catalytic activities of toluene combustion over CLT zeolite-supported Co, Fe, and Mn catalysts. They found the Na-CLT-supported Mn catalyst (9.5 $\left.\mathrm{MnO}_{2} / \mathrm{NaCLT}\right)$ to give a $T_{93}$ of toluene at $350{ }^{\circ} \mathrm{C}$. Douglas et al. [52] synthesized a series of zeolite-supported $\mathrm{Cu}$ catalysts with varying $\mathrm{Cu}$ loadings (1-4 wt\%), and catalytic tests showed the optimum catalyst to be a zeolite $\mathrm{X}$-supported $\mathrm{Cu}$ catalyst ( $\mathrm{Cu}$ loading at 1 wt\%) giving a $T_{98}$ at as low as $263^{\circ} \mathrm{C}$. This feature is strongly related to high dispersion of $\mathrm{Cu}$ species in the micropores. Notably, although these supported transition metal catalysts show good catalytic activities in the combustion of aromatics, their activities are still much lower than those of supported noble metal catalysts. Therefore, supported noble metal catalysts are still dominant in industrial applications.

\subsection{Catalytic combustion of methane}

Methane is typical greenhouse gas, whose greenhouse effect is 23 times that of $\mathrm{CO}_{2}[53,54]$. Table 2 presents the catalytic activity with respect to methane combustion over various zeolite-supported Pd catalysts. Park et al. [55] studied catalytic conversion of methane as a function of zeolite structure, suggesting that the intersecting 10-member and 8-member ring porous structures of zeolites have better dispersed and

\section{Table 2}

Catalytic activities in methane combustion over various zeolite-supported catalysts.

\begin{tabular}{lccccc}
\hline Catalyst & $\begin{array}{c}\text { VOCs concentra- } \\
\text { tion (ppm) }\end{array}$ & $\begin{array}{c}\text { GHSV } \\
\left(\mathrm{h}^{-1}\right)\end{array}$ & $\begin{array}{c}T_{50} \\
\left({ }^{\circ} \mathrm{C}\right)\end{array}$ & $\begin{array}{c}T_{90} \\
\left({ }^{\circ} \mathrm{C}\right)\end{array}$ & Ref. \\
\hline $1.3 \mathrm{Pd} \% / \mathrm{H}-\mathrm{TNU}-10$ & 10000 & 171326 & 380 & 425 & {$[55]$} \\
$1.2 \mathrm{Pd} \% / \mathrm{H}-\mathrm{ZSM}-5$ & 10000 & 171326 & 420 & 485 & {$[55]$} \\
$2.5 \mathrm{Pd} \% / \mathrm{H}-\mathrm{Beta}$ & 10000 & 171326 & 395 & 450 & {$[55]$} \\
$2.5 \mathrm{Pd} \% / \mathrm{H}-\mathrm{USY}$ & 10000 & 171326 & 415 & 475 & {$[55]$} \\
$3.4 \% \mathrm{Pd} / \mathrm{HZSM}-5$ & 10000 & 30000 & 255 & - & {$[56]$} \\
$4.2 \% \mathrm{Pd} / \gamma-\mathrm{Al}_{2} \mathrm{O}_{3}$ & 10000 & 30000 & 325 & - & {$[56]$} \\
\hline
\end{tabular}

stable PdO nanoparticles than zeolites with uniform 10-member ring and 12-member ring porous structures. As a result, $\mathrm{Pd} / \mathrm{H}-\mathrm{TUN}-10$ exhibits the highest combustion activity, together with excellent durability in the presence of water vapor from the catalysts studied. Later, Li et al. [56] reported Pd/HZSM-5 to have excellent combustion activity, giving $T_{50}$ for methane as low as $255^{\circ} \mathrm{C}$. The high activity is dependent on the weak Pd-O bond in the catalyst, which has been confirmed by CO temperature profile reduction tests of the catalyst.

\subsection{Total oxidation of formaldehyde}

Formaldehyde is a well-known indoor pollutant, which poses significant risk to human health [57-63]. Particularly, total oxidation of formaldehyde at room temperature has attracted much attention, where the major active centers are noble metals and the major supports being lattice-oxygen rich oxides, such as $\mathrm{TiO}_{2}[64,65], \mathrm{Fe}_{2} \mathrm{O}_{3}[66], \mathrm{CeO}_{2}$ [67] and $\mathrm{MnO}_{2}$ [68]. More recently, Park et al. [69] employed zeolites to support Pd as catalysts for the catalytic combustion of formaldehyde, as presented in Table 3 . Interestingly, under the same conditions, the zeolite-supported Pd catalysts exhibit much higher activities in formaldehyde combustion than the oxide-supported Pd catalysts. Furthermore, it has been observed that the catalytic conversion also depends on the zeolite structure. For example, the Beta zeolite-supported Pd catalyst $(0.25 \% \mathrm{Pd} /$ Beta $)$ has a conversion of $80 \% 40{ }^{\circ} \mathrm{C}$, while a conversion of only $30 \%$ was observed when employing a ZSM-5 zeolite-supported $\mathrm{Pd}$ catalyst $(0.25 \% \mathrm{Pd} / \mathrm{ZSM}-5)$ under the same conditions. Notably, one future scientific goal, which still remains a challenge in this field, is the full conversion of formaldehyde at room temperature over the zeolite-supported metal catalysts.

\subsection{Catalytic combustion of halogenated VOCs}

The highly poisonous halogenated VOCs-usually designated as CVOCs-have higher catalytic combustion temperatures than those of conventional VOCs. In the reported CVOC catalysts, zeolite-supported metal catalysts are particularly studied. Table 4 presents catalytic activities for the catalytic combustion of CVOCs over various zeolite-supported metal catalysts.

It has been reported that acidic zeolites (H-form) are catalytically active to convert CVOCs. For instance, Fonseca et al. [70] reported the catalytic combustion of dichloromethane over

Table 3

Catalytic activities in formaldehyde combustion over zeolite-supported Pd catalysts [64].

\begin{tabular}{lcccc}
\hline Catalyst & $\begin{array}{c}\text { VOCs concen- } \\
\text { tration }(\mathrm{ppm})\end{array}$ & $\begin{array}{c}\mathrm{GHSV} \\
\left(\mathrm{h}^{-1}\right)\end{array}$ & $\begin{array}{c}T_{50} \\
\left({ }^{\circ} \mathrm{C}\right)\end{array}$ & $\begin{array}{c}T_{100} \\
\left({ }^{\circ} \mathrm{C}\right)\end{array}$ \\
\hline $0.25 \%$ Pd/Beta & 40 & 50000 & $<40$ & 100 \\
$0.25 \%$ Pd/Zeo-13X & 40 & 50000 & $<40$ & 100 \\
$0.25 \%$ Pd/USY & 40 & 50000 & $<40$ & 100 \\
$0.25 \%$ Pd/ZSM5 & 40 & 50000 & $>60$ & 100 \\
$0.25 \%$ Pd/HM & 40 & 50000 & $>140$ & - \\
\hline
\end{tabular}


Table 4

Catalytic activities for the combustion of CVOCs over zeolite-supported metal catalysts.

\begin{tabular}{|c|c|c|c|c|c|c|}
\hline Catalyst & VOCs & VOC concentration (ppm) & GHSV $\left(h^{-1}\right)$ & $T_{50}\left({ }^{\circ} \mathrm{C}\right)$ & $T_{98}\left({ }^{\circ} \mathrm{C}\right)$ & Ref. \\
\hline Pt/HFAU & Chlorobenzene & 667 & 18000 & 350 & - & [71] \\
\hline Co/ZSM5-107 & Chloromethane & 1500 & 15000 & $<375$ & 450 & [74] \\
\hline Ce/ZSM5-107 & Chloromethane & 1500 & 15000 & $<400$ & 450 & [74] \\
\hline Mn/ZSM5-107 & Chloromethane & 1500 & 15000 & 400 & 500 & [74] \\
\hline Fe/ZSM5-107 & Chloromethane & 1500 & 15000 & $>400$ & 550 & [74] \\
\hline Ce/ZSM5-30 & Chloromethane & 1500 & 15000 & 325 & 450 & [74] \\
\hline $\mathrm{CeO}_{2} / \mathrm{USY}$ & 1,2-Dichloroethane & 1000 & 10000 & 215 & 270 & [75] \\
\hline $\mathrm{CeO}_{2} / \mathrm{HY}$ & 1,2-Dichloroethane & 1000 & 10000 & 280 & 360 & [75] \\
\hline $\mathrm{CeO}_{2} / \mathrm{SSY}$ & 1,2-Dichloroethane & 1000 & 10000 & 210 & 290 & [75] \\
\hline HZSM-5 & 1,2-Dichloroethane & 1000 & 15000 & - & 500 & [76] \\
\hline $9 \% \mathrm{Cr} / \mathrm{HZSM}-5$ & 1,2-Dichloroethane & 1000 & 15000 & - & 325 & [76] \\
\hline $12 \% \mathrm{CeO}_{2} / \mathrm{HZSM}-5$ & 1,2-Dichloroethane & 1000 & 15000 & - & 350 & [76] \\
\hline $9 \% \mathrm{Cr}-12 \% \mathrm{CeO}_{2} / \mathrm{HZSM}-5$ & 1,2-Dichloroethane & 1000 & 15000 & - & 269 & [76] \\
\hline
\end{tabular}

HY, HZSM-5, and HMOR, giving the temperature for full conversion of the dichloromethane at $\sim 400{ }^{\circ} \mathrm{C}$. The high temperatures required means that the processes are energy intensive, therefore zeolite-supported metal catalysts that reduce the temperature for equivalent conversion of CVOCs, and thereby reducing energy consumption, is of interest. Early research focused on the preparation of zeolite-supported noble metal catalysts. Taralunga et al. [71] reported a HFAU zeolite-supported Pt catalyst, which showed much higher activity in the combustion of chlorobenzene than those of $\mathrm{SiO}_{2}$ and $\mathrm{Al}_{2} \mathrm{O}_{3}$-supported $\mathrm{Pt}$ catalysts.

Pinard et al. [72] investigated the influence of the acid-base properties of the zeolite in the catalytic oxidation of dichloromethane (DCM) over PtNaX and PtNaY catalysts. They proposed a general reaction mechanism involving mainly the transformation of DCM species adsorbed on acidic $\left(\mathrm{H}^{+}\right.$, alcaline cation) and basic (zeolite, framework oxygens) sites into chloromethoxy then hydroxymethoxy species, as shown in Scheme 4. Chloromethoxy species resulted from the elimination of $\mathrm{MCl}$ (or $\mathrm{HCl}$ ) from DCM adsorbed species undergoing a

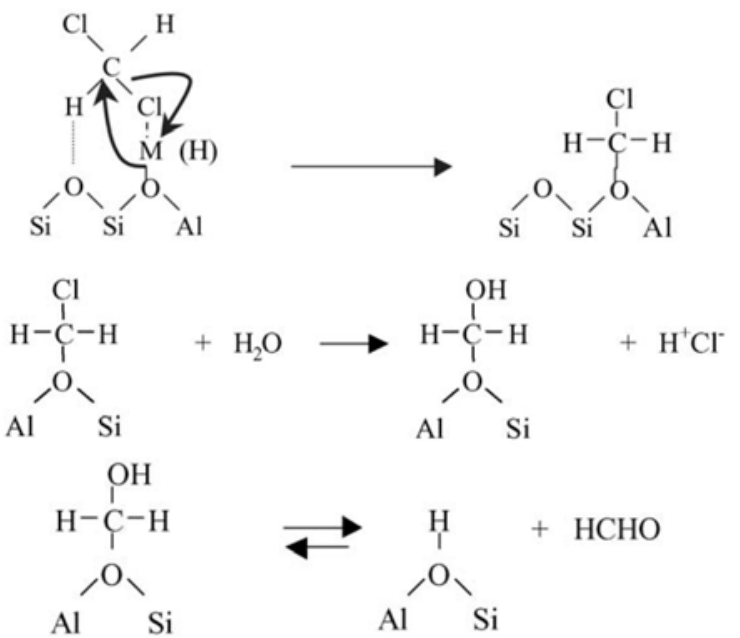

Scheme 4. Mechanism of DCM hydrolysis species. Reproduced from Ref. [72].
$\mathrm{SN}_{2}$ substitution leading to $\mathrm{HCl}$ and to hydroxymethoxy species in the presence of water. Thereafter, the hydroxymethoxy species, corresponding to formaldehyde molecules adsorbed on protonic sites of zeolites, decompose into formaldehyde and bridging hydroxyl groups.

However, the supported Pt catalysts suffer from deactivation as a result of the Pt species easily reacting with $\mathrm{Cl}$ in the organic compounds [73]. Therefore, supported noble metal catalysts are rarely used for the catalytic combustion of CVOCs. Researchers have since developed a series of supported transition metal catalysts for the combustion of CVOCs, which show good chloride-resistant properties [48]. Recently, zeolite-supported transition metal catalysts have received much attention because of their specific adsorptive properties.

Zhang et al. [74] have synthesized a series of ZSM-5 zeolite-supported metal catalysts ( $\mathrm{Co}, \mathrm{Fe}, \mathrm{Ce}, \mathrm{Mn}$ ) following an impregnation method for the combustion of $\mathrm{CH}_{3} \mathrm{Cl}$ and observed that the Co- and Ce-based catalysts possess higher activity than the corresponding Fe- and Mn-based catalysts. Later, Zhou et al. [75] showed that the supported transition metal oxide catalysts had higher activities than the supported transition metal catalysts, which suggests the importance of metal oxide lattice-oxygen species for the combustion of CVOCs. Recently, Yang et al. [76] prepared HZSM-5 zeolite-supported $\mathrm{CeO}_{2}$ and $\mathrm{Cr}_{2} \mathrm{O}_{3}$ catalysts $\left(9 \% \mathrm{Cr}-12 \% \mathrm{CeO}_{2} / \mathrm{HZSM}-5\right)$, which exhibited outstanding activity in the combustion of 1,2-dichloroethane, giving a $T_{98}$ at $269{ }^{\circ} \mathrm{C}$. The high activity is explained by the stronger oxidation ability from the interaction between $\mathrm{CeO}_{2}$ and $\mathrm{Cr}_{2} \mathrm{O}_{3}$. More importantly, this catalyst also exhibits excellent tolerance to coking and chloride poisoning. Such catalysts provide promising routes for the catalytic combustion of CVOCs.

\section{Plasma assisted catalytic combustion of VOCs}

Typical VOC gas concentrations are very low (ppm levels), and therefore there direct combustion is expensive and ineffective. To circumvent this problem, it is suggested to combine the processes of both adsorption and combustion, 
where the VOCs can be concentrated in the adsorbents, followed by the combustion of the VOCs. This combined process is thought to reduce energy costs. For example, Ogata et al. [77] showed that zeolite adsorbents in the presence of a plasma-assisted reactor for the combustion of VOCs should be recyclable and energy-saving process. Later, Trinh et al. [78] also reported the abatement of ethylene using a combination of non-thermal plasma and $\mathrm{Ag} /$ zeolite adsorbents. Notably, dilute ethylene was first adsorbed onto the catalyst over a period of 25 min before being plasma-catalytically oxidized. After adsorption, the plasma-oxidation of the adsorbed VOCs in the zeolite catalyst was catalytically transformed in a very short time. Since the plasma is only required during the catalytic conversion rather than adsorption process, the energy efficiency is relatively high. The outlook of VOC removal by combustion should look to combine various techniques to design more efficient and low-cost processes.

\section{Summary and outlook}

Recently, zeolite-based materials have been developed that exhibit many advantages for the removal of VOCs at low temperatures, which include energy-saving and environmentally friendly processes. A wealth of scientific research has been devoted to design highly efficient zeolite-based materials with excellent absorptive and catalytic properties for the removal of VOCs. Such properties are strongly dependent on the framework structure and pore size, $\mathrm{Si} / \mathrm{Al}$ ratio, cation types, adsorption selectivity in zeolites, and the heterogeneity of metal distribution on the zeolite supports as a function of their size.

Notably, the use of zeolites in the total oxidation of VOCs still faces challenges to improve deactivation and the economic viability of the zeolite catalysts. Catalyst deactivation is mainly attributed to coking of the zeolite surface during the catalytic process. There has been many studies to develop tailored hierarchical zeolites $[79,80]$, which have proven to significantly increase the catalysts' tolerance to coking [37]. Additionally, the relatively high cost of zeolite production is in the use of relatively expensive organic templates in the synthesis and the relatively low efficiency of hydrothermal routes. Sustainable routes (e.g. organotemplate-free and solvent-free) would remarkably reduce the cost of zeolites [81,82], which will widen their application. The outlook for VOC removal looks promising and developing zeolite catalysts with unique microporous or hierarchical structures at a lower cost would offer good opportunities to further design and prepare a series of highly efficient adsorbents and catalysts for the removal of VOCs.

\section{References}

[1] R. Atkinson, J. Arey, Chem. Rev., 2003, 103, 4605-4638.

[2] C. J. Weschler, Indoor Air, 2011, 21, 205-218.

[3] L. Pierre, Rev. Environ. Sci. Biotechnol., 2012, 11, 381-392.

[4] N. Imanaka, T. Masui, K. Yasuda, Chem. Lett., 2011, 40, 780-785.

[5] Y. Dai, X. Y. Wang, Q. G. Dai, D. Li, Appl. Catal. B, 2012, 111, 141-149.
[6] H. S. Moon, I. S. Kim, S. J Kang, S. K. Ryu, Carbon Lett., 2014, 15, 203-209.

[7] C. D. Cooper, C. A. Clausen, D. Tomlin, M. Hewett, A. Martinez, J. Hazard. Mater., 1991, 27, 273-285.

[8] C. McCullagh, N. Skillen, M. Adams, P. K. J. Robertson, J. Chem. Technol. Biotechnol., 2011, 86, 1002-1017.

[9] S. Delagrange, L. Pinard, J. M. Tatibouet, Appl. Catal. B, 2006, 68, 92-98.

[10] S. Scire, L. F. Liotta, Appl. Catal. B, 2012, 125, 222-246.

[11] S. Brosillon, M. H. Manero, J. N. Foussard, Environ. Sci. Technol., 2001, 35, 3571-3575.

[12] S. W. Lee, J. K. Cheon, H. J. Park, M. G. Lee, Korean J. Chem. Eng., 2008, 25, 1154-1159.

[13] H. K. Son, S. Sivakumar, M. J. Rood, B. J. Kim, J. Hazard. Mater., 2006, 301, 27-34.

[14] J. Choma, M. Marszewski, L. Osuchowski, J. Jagiello, A. Dziura, M. Jaroniec, ACS Sustain. Chem. Eng., 2015, 3, 733-742.

[15] P. Monneyron, M. H. Manero, J. N. Foussard, Environ. Sci. Technol., 2003, 37, 2410-2414.

[16] B. Dragoi, V. Rakic, E. Dumitriu, A. Auroux, J. Therm. Anal. Calorim., 2010, 99, 733-740.

[17] H. C. Shin, J. W. Park, K. Park, H. C. Song, Environ. Pollut, 2002, 119, 227-236.

[18] K. J. Kim, H. G. Ahn, Microporous Mesoporous Mater., 2012, 152, 78-83.

[19] P. S. Chintawar, H. L. Greene, Appl. Catal. B, 1997, 14, 37-47.

[20] S. Bhatia, A. Z. Abdullah, C. T. Wong, J. Hazard. Mater., 2009, 163, 73-81.

[21] H. F. Huang, W. J. Rong, Y. Y. Gu, R. Q. Chang, H. F. Lu, Acta Sci. Circumst., 2014, 34, 3144-3151.

[22] M. G. Ahunbay, O. Karvan, A. Erdem-Senatalar, Microporous Mesoporous Mater., 2009, 115, 93-97.

[23] A. O. Yazaydin, R. W. Thompson, J. Phys. Chem. B, 2006, 110, 14458-14462.

[24] E. Güvenç, M. G. Ahunbay, J. Phys. Chem. C, 2012, 116, 21836-21843.

[25] N. Brodu, S. Sochard, C. Andriantsiferana, J. S. Pic, M. H. Manero, Environ. Technol., 2015, 36, 1807-1818.

[26] A. F. Cosseron, T. J. Daou, L. Tzanis, H. Nouali, I. Deroche, B. Coasne, V. Tchamber, Microporous Mesoporous Mater., 2013, 173, 147-154.

[27] S. Brosillon, M. H. Manero, J. N. Foussard, Environ. Technol., 1999, 21, 457-465.

[28] A. Corma, C. Corell, J. Prez-Pariente, J. M. Guil, R. Guil-Lopez, S. Nicolopoulos, J. G. Callbet, M. Vallet-Regi, Zeolites, 1996, 16, 7-14.

[29] L. P. Zhou, L. Deng, Y. Kou, X. W. Li, Acta. Phys. Chim. Sin., 2002, 18, 142-146.

[30] D. A. Jones, T. P. Lelyveld, S. D. Mavrofidis, S. W. Kingman, N. J. Miles, Resour. Conserv. Recy., 2012, 34, 75-90.

[31] D. W. Price, P. S. Schmidt, J. Microw. Power Electrom. Energy, 1997, 32, 145-154.

[32] B. Legras, I. Polaert, M. Thomas, L. Estel, Appl. Therm. Eng., 2013, $57,164-171$.

[33] K. J. Kim, H. G. Ahn, Microporous Mesoporous Mater, 2012, 152, 78-83.

[34] A. Kodama, M. Goto, T. Hirose, T. Kuma, J. Chem. Eng. Jpn., 1993, 26, 530-535.

[35] A. Kodama, M. Goto, T. Hirose, T. Kuma, J. Chem. Eng. Jpn., 1995, 28, 19-24.

[36] H. Yamauchi, A. Kodama, T. Hirose, H. Okano, K. Yamada, Ind. Eng. Chem. Res., 2007, 46, 4316-4322.

[37] C. Y. Chen, J. Zhu, F. Chen, X. J. Meng, X. M. Zheng, X. H. Gao, F. S. 


\section{Graphical Abstract}

Chin. J. Catal., 2016, 37: 800-809 doi: 10.1016/S1872-2067(15)61073-7

Adsorptive and catalytic properties in the removal of volatile organic compounds over zeolite-based materials

Ling Zhang, Yuexin Peng, Juan Zhang, Long Chen, Xiangju Meng*, Feng-Shou Xiao*

Zhejiang University; East China Institute of Technology

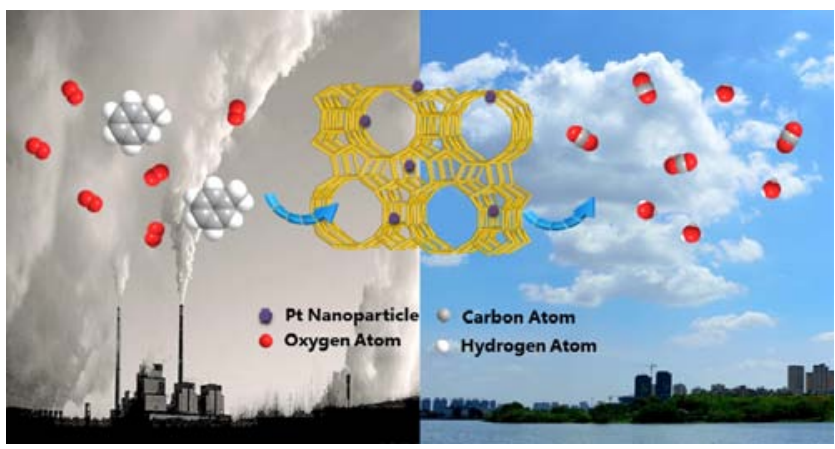

This paper reviews the recent progress of volatile organic compound removal over zeolite-based materials as adsorbents and catalysts, emphasizing the need to tailor specific properties, such as tuning of zeolite wettability and adsorption selectivity.

Xiao, Appl. Catal. B, 2013, 140, 199-205.

[38] C. Y. Chen, X. Wang, J. Zhang, S. X. Pan, C. Q. Bian, L. Wang, F. Chen, X. J. Meng, X. M. Zheng, F. S. Xiao, Catal. Lett., 2014, 144, 1851-1859.

[39] C. Y. Chen, X. Wang, J. Zhang, C. Q. Bian, S. X. Pan, F. Chen, X. J. Meng, X. M. Zheng, X. H. Gao, F. S. Xiao, Catal. Today, 2015, 258, 190-195.

[40] C. Y. Chen, Q. M. Wu, F. Chen, L. Zhang, S. X. Pan, C. Q. Bian, X. M. Zheng, X. J. Meng, F. S. Xiao, J. Mater. Chem. A, 2015, 3, 5556-5562.

[41] C. Y. Chen, F. Chen, L. Zhang, S. X. Pan, C. Q Bian., X. M. Zheng, X. J. Meng, F. S. Xiao, Chem. Commun., 2015, 51, 5936-5938.

[42] I. Mazzarino, A. A. Baresi, Catal. Today, 1993, 17, 335-347.

[43] N. Burgos, M. Paulis, M. M. Antxustegi, M. Montes, Appl. Catal. B, 2002, 38, 251-258.

[44] J. Tsou, P. Magnoux, M. Guisnet, J. J. M. Órfão, J. L. Figueiredo, Appl. Catal. B, 2005, 57, 117-123.

[45] R. Beauchet, P. Magnoux, J. Mijoin, Catal. Today, 2007, 124, 118-123.

[46] Z. K. Zhang, L. Y. Xu, Z. L. Wang, Y. J. Xu, Y. F. Chen, J. Nat. Gas Chem., 2010, 19, 417-421.

[47] H. L. Tidahy, S. Siffert, J. F. Lamonier, R. Cousin, E. A. Zhilinskaya, A. Aboukais, B. L. Su, X. Canet, G. D. Weireld, M. Frere, J. M. Giraudon, G. Leclercq, Appl. Catal. B, 2007, 70, 377-383.

[48] W. B. Li, J. X. Wang, H. Gong, Catal. Today, 2009, 148, 81-87.

[49] X. D. Zhang, Y. Wang, Y. Q. Yang, D. Chen, Acta Phys. Chim. Sin., 2015, 31, 1633-1646.

[50] G. S. P. Soylu, Z. Ôzcelik, I. Boz, Chem. Eng. J., 2010, 162, 380-387.

[51] Z. Őzcelik, G. S. P. Soylu, I. Boz, Chem. Eng. J., 2009, 155, 94-100.

[52] D. Romero, D. Chlala, M. Labaki, S. Royer, J. P. Bellat, I. Bezverkhyy, J. M. Giraudon, J. F. Lamonier, Catalysts, 2015, 5, 1479-1497.

[53] T. V. Choudhary, S. Banerjee, V. R. Choudhary, Appl. Catal. A, 2002, 234, 1-23.

[54] M. Johansson, T. Mattisson, A. Lyngfelt, Energy Fuels, 2006, 20 , 2399-2407.

[55] J. H. Park, B. Kim, C. H. Shin, G. Seo, S. H. Kim, S. B. Hong, Top Catal., 2009, 52, 27-34.
[56] Y. J. Li, J. N. Armor, Appl. Catal. B, 1994, 3, 275-282.

[57] X. F. Tang, Y. G. Li, X. M. Huang, Y. D. Xu, H. Q Zhu., J. G. Wang, W. J. Shen, Appl. Catal. B, 2006, 62, 265-273.

[58] C. B. Zhang, H. He, K. Tanaka, Appl. Catal. B, 2006, 65, 37-43.

[59] X. F. Tang, J. L. Chen, X. M. Huang, D. Xu, W. J. Shen, Appl. Catal. B, 2008, 81, 115-121.

[60] C. B. Zhang, H. He, K. Tanaka, Catal. Commun., 2005, 6, 211-214.

[61] C. Y. Li, Y. N. Shen, M. L. Jia, S. S. Shen, M. O. Adebajo, H. Y. Zhu, Catal. Commun., 2008, 9, 355-361.

[62] Y. N. Shen, X. Z. Yang, Y. Z. Wang, Y. B. Zhang, H. Y. Zhu, L. Gao, M. L. Jia, Appl. Catal. B, 2008, 79, 142-148.

[63] C. B. Zhang, F. D. Liu, Y. P. Zhai, H. Ariga, N. Yi, Y. C. Liu, K. Asakura, M. Flytzani-Stephanopoulos, H. He, Angew. Chem. Int. Ed., 2012, 51, 9628-9632.

[64] L. H. Nie, J. G. Yu, X. Y. Li, B. Chen, G. Liu, M. Jaroniec, Environ. Sci. Technol., 2013, 47, 2777-2783.

[65] H. B. Huang, D. Y. C. Leung, D. Q. Ye, J. Mater. Chem., 2011, 21, 9647-9652.

[66] N. H. An, Q. S. Yu, G. Liu, G. Liu, S. Y. Li, M. J. Jia, W. X. Zhang, J. Hazard. Mater., 2011, 186, 1392-1397.

[67] J. Zhang, Y. Jin, C. Y. Li, Y. N. Shen, L. Han., Z. X. Hu, X. W. Di, Z. L. Liu, Appl. Catal. B, 2009, 91, 11-20.

[68] X. H. Yu, J. H. He, D. H. Wang, Y. C. Hu, H. Tian, Z. C. He, J. Phys. Chem. C, 2012, 116, 851-860.

[69] S. J. Park, I. Bae, I. S. Nam, B. K. Cho, S. M. Jung, J. H. Lee, Chem. Eng. J., 2012, 195, 392-402.

[70] R. López-Fonseca, A. Aranzabal, P. Steltenpohl, J. I. Gutiérrez-Ortiz, J. R. González-Velasco, Catal. Today, 2000, 62, 367-377.

[71] M. Taralunga, J. Mijon, P. Magonoux, Appl. Catal. B, 2005, 60, 163-171.

[72] L. Pinard, J. Mijoin, P. Magnoux, M. Guisnet, C. R. Chim., 2005, 8, 457-463.

[73] R. Rachapudi, P. S. Chintawar, H. L. Greene, J. Catal., 1999, 185, 58-72.

[74] R. D. Zhang, B. Zhang, Z. Y. Shi, N. Liu, B. H. Chen, J. Mol. Catal. A, 2014, 398, 223-230.

[75] J. M. Zhou, L. Zhao, Q. Q. Huang, R. X. Zhou, X. K. Li, Catal. Lett., 
2009, 127, 277-284.

[76] P. Yang, X. M. Xu, Z. H. Meng, R. X. Zhou, Chem. Eng. J., 2013, 234, 203-210.

[77] S. M. Oh, H. H. Kim, H. Einaga, A. Ogata, S. Futamura, D. W. Park, Thin Solid Films, 2006, 506, 418-422.

[78] Q. H. Trinh, S. B. Lee, Y. S. Mok, J. Hazard. Mater., 2015, 285, 525-534.
[79] Y. Wei, T. E. Parmentier, K. P. de Jong, J. Zecevic, Chem. Soc. Rev., 2015, 44, 7243-7261.

[80] K. Moeller, T. Bein, Chem. Soc. Rev., 2013, 42, 3689-3707.

[81] X. J. Meng, F. S. Xiao, Chem. Rev., 2014, 114, 1521-1543.

[82] Q. M. Wu, X. Wang, G. Qi, Q. Guo, S. X. Pan, X. J. Meng, J. Xu, F. Deng, F. T. Fan, Z. C. Feng, C. Li, S. Maurer, U. Müller, F. S. Xiao, J. Am. Chem. Soc., 2014, 136, 4019-4025.

\section{沸石分子篮材料在消除挥发性有机化合物反应中的吸附与催化性能

\author{
章 凌 ${ }^{\mathrm{a}}$, 彭悦欣 ${ }^{\mathrm{a}}$, 张 娟, 陈 龙 ${ }^{\mathrm{b}}$, 孟祥举 ${ }^{\mathrm{a},}{ }^{*}$, 肖丰收 ${ }^{\mathrm{a}, \#}$ \\ a浙江大学化学系, 浙江省应用化学重点实验室, 浙江杭州 310017 \\ b东华理工大学化学生物与材料科学学院, 江西抚州 344000
}

摘要: 作为空气污染物的主要成分之一, 挥发性有机化合物 (VOCs) 会极大地破坏生态环境并损害人体健康. 在众多消除 VOCs 的方法中, 吸附法由于操作简单、成本低廉的优势而在工业上得以广泛应用. 催化燃烧法则因去除效率高, 适用范围 广且无二次污染等优点被认为是 VOCs 消除最有效的手段之一.

目前, 活性炭是最常用的 VOCs 吸附剂, 但存在再生困难、抗湿性差、易燃等诸多问题. 与活性炭等常规吸附剂相比, 沸 石分子篮作为 VOCs 吸附剂其主要优势在于：(1)沸石分子篮的疏水性可调, 通过调控分子篮骨架的硅铝比可以调节分子 篮的亲疏水性, 高硅铝比的沸石分子篮有着优异的疏水性能, 从而可以有效降低在一定湿度条件下水对 VOCs 分子的竞争 吸附; (2)均一的孔径分布可以有效地进行分子识别, 从而使吸附剂对 VOCs 的选择性吸附性大大提高; (3)沸石分子笁一般 由硅铝构成, 本身不可燃且水热稳定性好, 因此能够与微波加热等其他手段相结合以降低吸附剂重生能耗, 提高操作安全 性; (4)沸石分子篎比表面积大, 吸附容量高, 是作为蜂窝转轮吸附技术中吸附剂的理想材料, 而该技术是目前工业大规模消 除VOCs 的研究热点. 因此, 沸石分子笁由于其独特的性质, 被视为一种简单高效、选择性好的 VOCs 吸附剂. 现阶段, 催化燃 烧VOCs 所使用的催化剂常用金属氧化物作为载体, 但是金属氧化物比表面积相对较小且孔道结构不均一, 因此严重影响 了催化剂对 VOCs 的催化燃烧效率, 限制了催化燃烧活性的提高. 而与金属氧化物载体相比, 沸石分子笁材料具有均一的孔 道结构以及相对较大的比表面积等优点, 而将具有较好吸附选择性和吸附容量的沸石分子篮作为载体, 负载活性组分后可 以实现催化剂催化燃烧性能的显著提高, 从而成为VOCs催化燃烧的理想催化剂.

本文综述了目前沸石分子篮材料作为吸附剂和催化剂载体的负载型催化剂消除各类VOCs 的研究进展. 对于沸石分子 篮作为VOCs 吸附剂, 我们小结了影响其吸附容量和吸附选择性的因素, 发现分子篮的孔道大小和阳离子类型与 VOCs 的 吸附情况密切相关. 在此基础上, 进一步简单介绍了分子笁蜂窝吸附转轮技术的研究现状. 对于沸石分子篎作为催化剂载 体, 我们总结了其用于各类VOCs 催化燃烧的研究情况, 如烷烃类、芳烃类和醛类等. 探究了催化性能的影响因素及相应的 催化机理, 发现分子篎的孔道结构、阳离子类型、硅铝比等都会显著影响沸石分子篎负载型催化剂的催化活性. 最后, 探讨 了沸石分子篮应用于VOCs 消除目前所存在的问题,同时展望了该领域未来的研究和发展方向.

关键词: 空气污染; 挥发性有机物; 沸石分子笁; 负载型催化剂; 催化燃烧

收稿日期: 2016-01-30. 接受日期: 2016-03-03. 出版日期: 2016-06-05.

*通讯联系人. 电话/传真: (0571)88273698; 电子信箱: mengxj@zju.edu.cn

\#通讯联系人. 电话/传真: (0571)88273698; 电子信箱: fsxiao@zju.edu.cn

基金来源：中央高校基本科研业务费专项资金 (2015XZZX004-04); 浙江省自然科学基金 (LR15B030001).

本文的英文电子版由Elsevier出版社在ScienceDirect上出版(http://www.sciencedirect.com/science/journal/18722067). 